\title{
The Impact Factors of College English Teaching Quality
}

\author{
Xi Sun ${ }^{1}$, Yuchi Zhu ${ }^{2}$ \\ ${ }^{1}$ Jiangxi Police Institute, Nan Chang, Jiangxi, 330103
}

KEYWORDS: College English Teaching; Affecting Factors; Teaching Quality

\begin{abstract}
College English courses involve guiding ideology, training objectives, teaching principles and corresponding teaching content, teaching methods, test content and test methods and other issues. These issues also involve the concept of education, teachers' conception of qualified personnel, quality concept and other concepts and methodology. 21st century new economy, new ideas and new methods require. Therefore, we should examine higher education college English teaching quality from ideas and new angles rules of market economy.
\end{abstract}

\section{Introduction}

In the growing globalization context, our cooperation with the international cross-cultural communication is becoming more frequent. As a world-wide official language, English is not only the countries of mutual communication and collaboration tool, is becoming an essential requirement for our era presented. "College English" as the culture of Undergraduate Talents in an important basic course, its security and improve the quality of teaching has become the realization of China's reform objectives of English teaching an eternal theme. China's education gradually change from the previous exam-oriented education to quality education direction and goal of college English teaching from the previous emphasis on reading and writing skills of a gradual transition to the current focus on training college students' English language proficiency, meet the needs of the job market in different periods, It conforms to the trend of education reform. As a teacher preaching Tuition FAQ's place, the quality of teaching college English classroom directly affects the overall quality of students' English ability. How to improve and protect the quality of their teaching is the problem of parents, universities and social constituents are very concerned about, and its importance cannot be ignored. On the basis of the content and grasp the new requirements of the college English teaching, construct a more perfect teaching quality assurance system, in the importance of quality education today, it has an extremely important theoretical and practical significance.

\section{Situation of College English Teaching Quality}

College English is almost all Chinese universities opened all the public courses, teaching hours and more on the quality of students, career or further study the impact is very large. Reform and opening up 30 years ago, English teaching in Chinese universities has made remarkable achievements. Teachers in the expanding number of English professional graduates and master's and doctoral graduates to enrich a certain number of teachers, and become the backbone of English teaching. It sets the number of different versions of the materials increased, appeared in Foreign Language Teaching and Research Press, Higher Education Press, Shanghai Foreign Language Education Press as a leader of a foreign language textbook publishing groups. Write quality materials improved steadily, new educational ideas gradually reflected in the new textbooks in 
preparation, from the past to prepare structuralism system as the core language knowledge into student-centered task-based, theme-oriented textbook compilation system. Greatly improved the quality of teaching, students 'listening, speaking, reading and writing skills have significantly enhanced, all types of students' oral contests, speech contests, translation contest, essay contest and so the selection of English proficiency outstanding talent. Universities all walks of life while conveying a lot of Jidong professional has a certain ability to use foreign language professionals. After the 1980s, our country every year tens of thousands of high school students to study abroad, most of these students has laid a good foundation in foreign languages, with good results by a variety of foreign language skills test. However, in the full recognition of university English teaching quality achieved greatly improved at the same time, we also found that the actual input language proficiency and teaching of university students there are still relatively large contrast, is a large gap between investment and return. From junior high school, and even start primary school until graduation, if the average 5 hours per week, 18 weeks per semester count, 3-year primary school, secondary school for six years, the University of 2 years, a total of 11 years, 22 semesters, each student spend time on learning English close to 2000 hours. However, after graduating from college English really be called "tricks" that can be used for general English communication, reading books in English professional who will probably not exceed 50\%. For many college students by the University of CET, almost 2012 university study before a significant portion of time is spent on English. Not to mention a considerable portion of students are still not passed, even university graduates have passed this exam is difficult to say the actual level of English has reached a "College English Curriculum Requirements" raised. Students' language output skills, especially skills spoken and written relatively weak, not well adapted to the actual needs of social development. Many schools blind pursuit CET high pass rate and excellent high rate, even at the use of the sea tactical intensive training and examination of ways, serious damage to the internal laws of language teaching. With the popularization of higher education at the same time the popularity of expansion of enrollment, quality and distribution of students vary, inadequate preparation of teachers, management and teaching facilities, has been affected in some way to improve the quality of teaching college English, teaching the idea is more suited to a potential threat to the quality of teaching.

\section{Factors Affecting English Teaching Quality}

The primary factors associated with the quality of teaching students. Factors Affecting the Teaching Quality of students with mental factors and non-intelligence factors. The former is more complicated, because the university is English public courses, the large number of great intellectual gap between foreign language. Despite this, we still have to be individualized as possible. Through scientific intelligence tests, divided into different learning groups, organizations targeted teaching, rather than to adopt a uniform teaching. The quality of teaching non-intelligence factors include: 1) Motivation: Students take exams for course credit and cope with school, or to go abroad, job or higher education and learning different motives have different needs?. 2) Requirements: students want to improve academic ability, communicative ability, or the ability to work need to improve speaking ability, or the ability written ability to use different needs have different expectations. 3) Expectations: Students expect to make their college English courses to what standards are high expectations of contemporary college students, they know social standards and market demand for talent?. They expect consistent with university English courses. In addition, students expect teachers to be teaching what ways? Indoctrination? Interactive? Different motivations, needs and expectations will lead to different learning attitude and approach. 
Teachers are teaching designers and provider host, of course, manufacturers of goods on the education market, is one of the determinants of the quality of teaching. The quality of teaching teachers include: 1) Education: a teacher's formal education qualifications and further education. Of course, formal education and less educated and career were also a lot of people, the key is later efforts. In the era of knowledge economy, knowledge update cycle faster, even if teachers have a master's degree, if you do not insist on further study, cannot be considered good educational background. 2) Professional level: as a college English class teacher should majoring in English in addition to professional outside, there should be foreign language education, applied linguistics, second language acquisition or TEFL other aspects of professional training. 3) Ability Education: high education and technical education is not equal to already have the educational capacity, the need to understand the principles of education, principles and laws, with all kinds of foreign language teaching ability (not just the ability to impart knowledge, and more importantly, good at training students to master language communicative competence). 4) Teaching attitude: whether college English teacher professionalism, due diligence, love of students, good teaching and learning is to become a professional teaching career whether or when the insatiable desire to learn, strive to maintain a challenge themselves and improve themselves or their quality is off the beaten path 5) Research and capacity: a university professor must possess research capabilities. Whether Ren Jiaozhe engaged in teaching and research for researchers to engage in teaching? Will use quantitative tools and qualitative methods? Good language study or the study of language teaching or language learning? Only teaching people just do not study "pedagogue."

Teaching methods is marketing course, even the best content or teaching materials, teaching methods, if not the way, students would not have IDA. Teaching methods and teaching concept, teachers' concept, students' conception of qualified personnel, quality concept closely linked. Teaching method can also be treated as a path, a clear guide, whither related to the students, the students into what kind of person. Traditional teaching foreign languages using indoctrination, grammar is the path to the sentence-based, teacher-centered classroom teaching; communicative approach using interactive, scenario-path to the function-oriented, student-language activities body; collaborative process approach adopted in the communication path, task-oriented, teachers and students together to complete the project. Imagine one without the guidance of the concept of modern education, teachers have not mastered the principles of the communicative approach, the traditional law professor instill materials prepared by the communicative approach, the result will be.

University Management College English Teaching Quality restricting coordination factors. Good college English teaching management, to the establishment of a stable teaching order, motivate teachers to improve teaching and student consciousness of self-education. The establishment of effective teaching command system in teaching, development and implementation of teaching management system of rules, the scientific organization of the teaching process, can give full play to the functions of teaching management, to ensure the normal operation of teaching work, to improve the efficiency of teaching, to improve the quality of teaching to provide effective protection. College English teaching should be managed through the whole process of college English teaching. By strengthening the teaching process guidance, supervision and inspection to ensure the college English teaching achieve the established teaching objectives. 2. Teaching Guarantee factors. Guaranteeing teaching is an important factor restricting the quality of teaching. School security system, including network infrastructure, information security, protection of material conditions of teaching, books, data protection and other aspects. Security system is to maintain the normal operation of teaching conditions, which guarantee any aspect of a problem 
occurs, will affect the normal operation of schools teaching all courses, including universities, including English, to improve the quality of teaching to improve adversely affected.

College English Teaching in a certain social environment, its openness determines the environmental factors that have an impact on the operation and evolution of college English teaching, and thus have an impact on the quality of teaching. Here to talk about environmental factors include social environment (such as the employer will forty-six as the strength and ability to judge whether graduate employment conditions), the teaching process environment (such as in forty-six other tests as "baton" examination-oriented education) nature and assessment of environmental education (CET, etc. in order to master the language knowledge as a basis to measure the level of English learners), affected by these factors, the purpose of college English teaching and language as a communication tool contrary, college students learning English scores Low Energy common occurrences. Above factors, interrelated, mutual restraint, interdependence and mutual influence, constitute the teaching system inside and outside the school and college English teaching process extremely complex contradictory relationship, which restricts the development of college English teaching quality. On school internal and external quality factors, the impact of factors play a decisive role within the school. Internal factors in the school, and play a leading role in the teaching process of teaching and learning of the two major factors play a key role in teaching management factors. Teaching quality will depend on the above factors and active process of coordination and control process, which is the all-round quality of teaching work, system-wide management.

\section{Conclusion}

As can be seen from the above analysis, factors affecting college English teaching are various. But the key is to determine the appropriate target, so that students have the right motivation, to create a good classroom and after-school learning environment, establish a higher level of business, education level and professionalism, innovative teachers and the establishment of a sound teaching management and service system.

\section{Reference:}

[1] Cook.V. Second Language Learning and Language Teaching [M]. Beijing: Foreign Language Teaching and Research Press, 2000.

[2] Ellis, R. The Study of Second Language Acquisition [M]. Shanghai: Shanghai Foreign Language Education Press, 1994. 478 493.

[3] Johnson K. An Introduction to Foreign Language Learning and Teaching [M]. Beijing: Foreign Language Teaching and Research Press, 2002.

[4] Stern, H. H. Fundamental Concepts of Language Teaching [M]. Oxford: Oxford University Press, 1983: 376. 